\title{
Eksplorasi Bakteri Diazotrof dari Rizosfer Tanaman Bawah Merah (Allium ascalonicum L.) di Brebes, Jawa Tengah
}

\author{
Dwi Ayu Lutfiani Amalia', Oedjijono', Purwanto $^{2}$ \\ ${ }^{1}$ Fakultas Biologi, Universitas Jenderal Soedirman \\ ${ }^{2}$ Jurusan Agroteknologi, Fakultas Pertaninan, Universitas Jenderal Soedirman \\ Jalan dr. Suparno 63 Purwokerto 53122 \\ email: oedjijono@unsoed.ac.id
}

\begin{abstract}
Rekam Jejak Artikel:
Diterima : 08/11/2020

Disetujui : 22/12/2020
\end{abstract}

\begin{abstract}
This study aims to explore the diazotroph bacteria that are able to produce nitrogen and produce the IAA hormone by selecting it from the rhizosphere of the shallots plant in Brebes, Central Java. The research design used was a survey method. This research consisted of taking samples of shallot rooting soil in Brebes, Central Java, isolation of soil bacteria in Yeast Mannitol Agar, Ashby, and Caceres medium, IAA production test of nitrogen-fixing quantitative test using Kjeldahl analysis, and bacterial characterization. A total of nine diazotroph bacterial isolats capable of producing IAA were successfully isolated. The nine isolats were able to produce IAA with concentrations between $305-3.51 \mathrm{ppm}$, with LAR3 isolats as the highest IAA producer. The results of total nitrogen levels by the Kjeldahl method of the 6 best isolats producing IAA, were able to produce concentrations ranging from 3.15 to $88.55 \mathrm{ppm}$. LAR5 isolats was the highest nitrogen producer. Identification results showed that the nine bacterial isolats obtained were included in 3 different bacterial groups, four isolats including species belonging to the genus Rhizobium (isolats LAR3, LAR5, LBR1, and LCR3), three isolats including species belonging to the genus Azospirillum (isolats LAA4, LAA5, and LCA1), and two isolats including species belonging to the genus Azotobacter (isolats LBZ2 and LBZ2).

Key Words : Diazotrof bacteria, IAA, Nitrogen fixation, Shallots.
\end{abstract}

\begin{abstract}
Abstrak
Penelitian ini bertujuan untuk mengeksplorasi bakteri diazotrof yang mampu menambat nitrogen dan menghasilkan hormon IAA dengan cara menyeleksinya dari rizosfer tanaman bawang merah di Brebes, Jawa Tengah. Penelitian ini terdiri dari pengambilan sampel tanah perakaran bawang merah di Brebes, Jawa Tengah, isolasi bakteri tanah pada medium Yeast Mannitol Agar+Congo red, Ashby, dan Caceres, uji produksi IAA metode Salkowski, uji kemampuan penambatan nitrogen metode Kjeldahl, dan identifikasi bakteri. Sebanyak sembilan isolat bakteri diazotrof yang mampu menghasilkan IAA telah berhasil diisolasi. Kesembilan isolat tersebut mampu menghasilkan IAA dengan konstentrasi antara 3,05-3,51 ppm, dengan isolat LAR3 sebagai penghasil IAA tertinggi. Hasil perhitungan kemampuan menambat nitrogen bebas dengan metode Kjeldahl menunjukkan bahwa 6 isolat penghasil IAA terbaik mampu menghasilkan nitrogen total dengan konsentrasi berkisar antara 3,15-88,55 ppm. Isolat LAR5 merupakan penghasil nitrogen tertinggi. Hasil identifikasi menunjukkan kesembilan isolat bakteri yang didapatkan termasuk dalam 3 kelompok bakteri yang berbeda, yaitu empat isolat termasuk spesies anggota genus Rhizobium (isolat LAR3,LAR5,LBR1,dan LCR3), tiga isolat adalah spesies anggota genus Azospirillum (isolat LAA4,LAA5, dan LCA1), dan dua isolat termasuk spesies anggota genus Azotobacter (isolat LBZ2 dan LBZ3).
\end{abstract}

Kata Kunci : Bakteri Diazotrof, IAA, Fiksasi Nitrogen, Bawang Merah.

\section{PENDAHULUAN}

Bawang merah merupakan komoditas sayuran penting di Indonesia, tanaman ini biasa tumbuh di tanah Entisol (Alluvial). Tanah jenis Entisol atau Alluvial merupakan tanah dengan protoplasma, molekul klorofil, asam nukleat, dan asam amino (Nasikah, 2007). Udara mengandung kadar bahan organik dan $\mathrm{N}$-total yang tergolong sangat rendah (Firmansyah et al., 2015). Nitrogen merupakan salah satu unsur hara utama yang dibutuhkan oleh tanaman dalam jumlah besar dan bermanfaat bagi tanaman sebagai penyusun sekitar $78 \% \mathrm{~N}$, tetapi tanaman tidak dapat menggunakan secara langsung, sehingga pupuk $\mathrm{N}$ 
selalu ditambahkan sebagai input produksi tanaman (Hindersah \& Simarmata, 2004). Petani menggunakan sumber nitrogen tambahan ke dalam tanah dalam bentuk pupuk anorganik, seperti urea, ZA, dan NPK. Hal ini mendorong pemakaian pupuk anorganik terus meningkat (Nasikah, 2007).

Penggunaan pupuk bersubsidi untuk mencukupi kebutuhan nitrogen setiap tahunnya mengalami peningkatan, yaitu setiap tahun naik sebesar $6,11 \%$. Kebutuhan pupuk urea bersubsidi tahun 2010 sebesar Rp. 6.791.811 triliun, meningkat menjadi Rp. 9.178.602 triliun pada tahun 2015 (APPI, 2015). Peningkatan tersebut berdampak meningkatnya anggaran subsidi pupuk setiap tahunnya, namun hasil panen yang didapat tidak sebanding dengan pemupukan yang telah diberikan. Menurut Saragih et al. (2013), pemberian pupuk urea dosis $285 \mathrm{~kg}$ urea/ha mampu meningkatkan bobot kering berangkasan, namun nitrogen yang diserap hanya 7,74 $\mathrm{kg}$ urea/ha. Menurut Danapriatna (2010), sebagian nitrogen dari pupuk urea yang diaplikasikan hilang melalui beberapa mekanisme termasuk volatilisasi amonia, denitrifikasi, dan pencucian, dan mengakibatkan munculnya masalah polusi terhadap lingkungan. Upaya dalam pengurangan penggunaan pupuk anorganik terus ditingkatkan, salah satunya adalah pemanfaatan bakteri diazotrof dalam penggunaan pupuk hayati (Panjaitan et al., 2015).

Bakteri diazotrof merupakan bakteri yang mampu menambat $\mathrm{N}$ udara (Widyawati et al., 2014). Bakteri tersebut juga mampu memberikan efek menguntungkan bagi pertumbuhan tanaman atau disebut sebagai Plant Growth Promoting Rhizobacteria (PGPR) melalui kemampuan penghasilan hormon tanaman (indoleacetic acid, asam giberelat, sitokinin), pelarutan fosfat anorganik, pengurangan etilen, pengendalian patogen, produksi siderofor, dan produksi $\beta-1,3$, glukanase (Tilak et al., 2010). Beberapa contoh bakteri diazotrof adalah Azotobacter, Azospirillum, dan Rhizobium. Inokulasi Rhizobium pada tanaman padi dapat meningkatkan panjang akar total dan produksi biomassa (Islam et al., 2019; Purwanto et al., 2017).

Tujuan dari penelitian ini adalah mengisolasi bakteri diazotrof dari rizosfer bawang merah (Allium ascalonicum L.); (2) mengetahui kemampuan isolat bakteri diazotrof dari rizosfer bawang merah dalam menghasilkan hormon IAA dan menambat nitrogen secara kuantitatif; dan (3) mengetahui identitas bakteri diazotrof dari rizosfer bawang merah yang mampu menghasilkan IAA.

\section{MATERI DAN METODE}

\section{Pengambilan Sampel Rizosfer}

Sampel tanah rizosfer berasal dari lahan pertanian bawang merah di Brebes. Sampel tanah diambil dari 3 lokasi berbeda yaitu desa Larangan, Dukuhturi, dan Karangbale Kecamatan Larangan, Kabupaten Brebes, Jawa Tengah. Tanah diambil dengan mencabut tanaman bawang merah, kemudian sampel tanah yang akan digunakan adalah tanah pada sisa akar dan dimasukan ke dalam plastik. Nilai $\mathrm{pH}$ dan kelembaban tanah diukur menggunakan soil tester, pengukuran suhu tanah meggunakan termometer, pengukuran dilakukan secara in situ.

\section{Isolasi Bakteri (modifikasi dari Oedjijono et al., 2014)}

Sebanyak $10 \mathrm{~g}$ sampel tanah dicampurkan dengan $90 \mathrm{~mL}$ akuades steril, kemudian dilakukan pengenceran bertingkat dengan cara mengambil sebanyak $1 \mathrm{~mL}$ dicampurkan dengan akuades steril $9 \mathrm{~mL}$ dan didapatkan pengenceran $10^{-2}$, selanjutnya dilakukan pengenceran bertingkat sampai dengan $10^{-6}$. Sebanyak $0,1 \mathrm{~mL}$ dari dua pengenceran terakhir diinokulasikan pada medium Caceres, medium YMA+ congo red, dan medium Asbhy secara spread plate dan masing-masing media 
diinkubasi selama 2-4 x 24 jam suhu ruang. Isolat yang tumbuh dan berbeda dilakukan pemurnian, kemudian disimpan dalam medium agar miring.

\section{Pembuatan Kurva Standar IAA}

Larutan standar IAA konsentrasi 0, 2, 4, 6, 8, dan $10 \mathrm{mg} / \mathrm{L}$ dibuat dengan cara dilarutkan dengan metanol. Sebanyak $0,5 \mathrm{~mL}$ larutan IAA dari masing-masing konsentrasi tersebut dicampurkan reagen Salkowski $1,5 \mathrm{~mL}\left(150 \mathrm{~mL} \mathrm{H}_{2} \mathrm{SO}_{4}, 250 \mathrm{~mL}\right.$ akuades dan 7,5 $\mathrm{mL} \mathrm{FeCl}_{3} 6 \mathrm{H}_{2} \mathrm{O}$ ) dan diinkubasi di ruang gelap selama 30 menit. Larutan selanjutnya diukur absorbansinya pada spektrofotometer dengan panjang gelombang $530 \mathrm{~nm}$. Nilai absorbansi dari setiap konsentrasi dibuat kurva regresi untuk mendapatkan kurva standar dan persamaan IAA.

Uji Kemampuan Isolat Bakteri Diazotrof dalam Menghasilkan IAA (modifikasi dari Reetha et al.,2014)

Uji Produksi IAA dilakukan dengan menumbuhkan isolat bakteri pada $10 \mathrm{~mL}$ medium $\mathrm{NB}+$ L-Triptofan 2\%, diinkubasi 1 x 24 jam. Larutan kemudian disentrifugasi pada sentrifuse dengan kecepatan 4.500 rpm (RCFxg 2422) selama 10 menit. Sebanyak 0,5 mL supernatan diambil dan ditambahkan ke dalamnya $1,5 \mathrm{~mL}$ reagen Salkowski, kemudian diinkubasi pada ruang gelap selama 30 menit. Larutan selanjutnya diukur absorbansinya menggunakan spektrofotometer dengan panjang gelombang $530 \mathrm{~nm}$. Nilai absorbansi ditiap sampel kemudian dimasukan ke dalam persamaan IAA, sehingga diperoleh konsentrasi IAA isolat.

\section{Uji Kemampuan Bakteri Diazotrof dalam Menambat $\mathrm{N}_{2}$ (Oedjijono et al., 2014)}

Kadar $\mathrm{N}_{2}$ yang mampu ditambat oleh bakteri diazotrof diukur dengan menggunakan metode Kjeldahl. Sebanyak 2 isolat dari masing-masing genus ditumbuhkan dalam medium selektif NfB semipadat untuk isolat LAA4 dan LAA5, medium
YMA untuk isolat LAR3 dan LARH5, dan medium Asbhy untuk isolat LAZ2 dan LAZ3. Masingmasing kultur diinkubasi selama 10-20 hari pada suhu ruang. Kultur bakteri yang tumbuh dimasukan ke dalam labu Kjeldahl yang berisi campuran garam (perbandingan yang digunakan 40: 2,5: 1,5 dari $\mathrm{K}_{2} \mathrm{SO}_{4}, \mathrm{CuSO}_{4}$ dan logam selenium), kemudian 3 $\mathrm{mL}$ asam sulfat pekat ditambahkan ke dalam labu Kjeldahl. Labu kemudian dipanaskan di lemari asam pada Digester pada suhu $420^{\circ} \mathrm{C}$ selama 20 menit. Setelah melalui proses tersebut, labu kemudian didinginkan dengan ditambahkan akuades mencapai volume akhir $50 \mathrm{~mL}$. Sebanyak $20 \mathrm{~mL}$ sampel digesti dituangkan ke dalam tabung destilasi kemudian dimasukkan pada alat destilasi. Labu Erlenmeyer $250 \mathrm{~mL}$ yang berisi $20 \mathrm{~mL}$ asam borat $4 \%$ dan 6 tetes Conway reagen (1000mg methyl red, $150 \mathrm{mg}$ bromcresol green, 200ml etanol 96\%) ditempatkan di bawah kondensor peralatan distilasi dan ujung outlet kondensor berada di bawah larutan. Distilasi dilakukan dengan menggunakan unit distilasi Semiotomatis, kemudian sebanyak $30 \mathrm{~mL} \mathrm{NaOH} 40 \%$ dan 100 $\mathrm{mL}$ akuades secara otomatis dituangkan melalui peralatan pada destilator. Larutan yang mengandung $\mathrm{NH}_{3}$, asam borat dan indikator campuran pada Erlenmeyer 250mL dititrasi dengan $0,05 \mathrm{~N} \mathrm{HCl}$ menggunakan Autotitrator. Jumlah konsentrasi $\mathrm{N}_{2}$ pada sampel dapat dihitung melalui persamaan:

$$
\mathrm{N} \text { total }(\mathrm{ppm})=\frac{\mathrm{a}-\mathrm{bx} \mathrm{Nx} 14 \times 1000000}{\mathrm{c}(\mathrm{g}) \times 1000}
$$

Keterangan:

a : Sampel Titer

$\mathrm{b}$ : Titer Blanko

c : Berat Sampel

$\mathrm{N}$ : Normalitas $\mathrm{HCl}$

\section{Pengamatan Makromorfologi Koloni Bakteri}

Karakter makromorfologi yang diamati antara lain bentuk koloni, ukuran koloni, tepi 
koloni, warna koloni, elevasi dan permukaan koloni pada medium selektif.

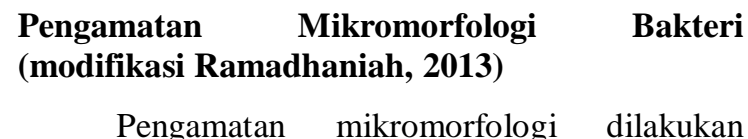
dengan pewarnaan Gram. Sebanyak satu ose kultur diulas di object glass. Inokulum difiksasi dengan melewatkan sampel yang berada di object glass di atas api. Pewarna karbol Crystal violet diteteskan di atas glass dan didiamkan selama \pm 1 menit kemudian dicuci dengan akuades mengalir dan dikeringkan. Lugol's iodine kemudian diteteskan di atas object glass dan didiamkan selama 40-60 detik, cuci dengan akuades dan keringkan. Larutan alkohol 96\% diteteskan pada object glass selama 1 menit, kemudian dicuci dengan akuades megalir dan dikeringanginkan. Larutan safranin diteteskan di atas object glass dan didiamkan selama \pm 45 detik kemudian dicuci dengan akuades mengalir dan dikeringanginkan. Hasil pewarnaan Gram diamati pada mikroskop. Sel bakteri Gram positif akan terwarnai menjadi ungu, sedangkan Gram negatif terwarnai menjadi merah. Pengamatan karakter Gram dan bentuk sel bakteri diamati menggunakan mikroskop cahaya dengan perbesaran $10 \times 100$.

Uji Motilitas (modifikasi Sirois 2014, 2008)

Disiapkan tusuk steril dan medium SIM A, kemudian ambil sebanyak satu ose koloni tunggal dengan tusuk steril secara aseptis dan diinokulasikan ke dalam medium SIM A secara tegak lurus, kemudian diinkubasi selama 24 jam pada suhu ruang.

Uji Pengaruh Suhu (modifikasi Adiguzel et al., 2011)

Pengujian pengaruh suhu dilakukan dengan cara koloni pada media miring diambil sebanyak 1 ose, kemudian diinokulasikan pada medium NB. Kultur bakteri diinkubasi pada suhu ruang, $37^{\circ} \mathrm{C}$, dan $50^{\circ} \mathrm{C}$. Inkubasi dilakukan selama 1 x 24 jam. Hasil diinterpretasikan positif apabila medium menjadi keruh dan negatif apabila tidak ada perubahan pada medium (tetap bening).

Uji Pengaruh pH (modifikasi Adiguzel et al., 2011)

Pengujian $\mathrm{pH}$ dilakukan dengan cara mengambil sebanyak 1 ose isolat pada medium NA miring, kemudian dinokulasikan ke dalam medium NB dengan pH 4, 7 dan 9. Kultur bakteri kemudian diinkubasi selama 1 x 24 jam. Hasil diinterpretasikan positif apabila medium menjadi keruh dan negatif apabila tidak ada perubahan pada medium (tetap bening).

\section{Uji Salinitas (modifikasi Adiguzel et al., 2011)}

Pengujian salinitas dilakukan dengan cara mengambil sebanyak 1 ose isolat pada medium NA miring, kemudian dinokulasikan ke dalam medium $\mathrm{NB}$ dengan penambahan $\mathrm{NaCl} 3 \%, 5 \%$ dan $7 \%$. Kultur bakteri diinkubasi selama 1 x 24 jam. Hasil diinterpretasikan positif apabila medium menjadi keruh dan negatif apabila tidak ada perubahan pada medium (tetap bening).

Uji Oksidase (modifikasi Ramadhaniah, 2013)

Koloni pada medium miring diulaskan pada kertas saring diatas object glass. Isolat bakteri ditetesi reaegen tetramethyl-p-phenylenediaminedihydricloride. Hasil diinterpretasikan positif apabila di bawah koloni berwarna biru kehitaman dan interpretasi negatif apabila tidak berubah warna.

Uji Katalase (Brown, 2007)

Koloni pada media miring diulaskan pada object glass, kemudian isolat bakteri ditetesi reagen $\mathrm{H}_{2} \mathrm{O}_{2}$. Interpretasi positif apabila terbentuk gelembung gas dan interpretasi negatif apabila tidak terbentuk gelembung gas.

Uji Produksi Asam Dari Karbohidrat (Lay, 1994)

Koloni pada media miring diambil sebanyak 1 ose. Selanjutnya,isolat bakteri diinokulasikan pada medium basal dengan ditambahkan gula dengan konsentrasi $5 \%$ yang diberi reagen phenol 
red dengan sumber gula dari glukosa, laktosa, dan sukrosa. Kultur bakteri masing-masing diinkubasi selama 1 x 24 jam pada suhu ruang. Hasil diinterpretasikan positif apabila medium menjadi kuning dan negatif apabila tidak ada perubahan pada medium.

\section{Uji Oksidatif Fermentatif (OF) (Lay 1994)}

Isolat diambil dengan tusuk steril dari medium agar miring, kemudian isolat diinokulasikan secara aseptis pada medium OF dengan stab inoculation. Sebagian dari medium OF yang sudah inokulasikan isolat bakteri ditetesi dengan paraffin. Semua kultur bakteri diinkubasi selama 2 x 24 jam pada suhu ruang. Setelah diinkubasi isolat diamati apabila bakteri fermentatif maka medium yang sudah diberi parafin akan berubah menjadi warna kuning. Apabila bakteri termasuk dalam sifat oksidatif, maka medium yang tidak ditutup parafin akan menjadi warna kuning. Apabila bakteri bersifat oksidatif fermentatif baik di medium yang ditutup oleh parafin dan yang tidak akan berubah menjadi warna kuning.

Uji Penggunaan Karbohidrat Sebagai Satusatunya Sumber Karbon untuk Pertumbuha Bakteri Diazotrof (Lay, 1994)

Koloni pada media miring diambil sebanyak 1 ose, kemudian isolat bakteri diinokulasikan pada medium basal dengan ditambahkan gula dengan konsentrasi 5\% dengan sumber gula dari glukosa, laktosa, maltosa dan sukrosa. Kultur bakteri diinkubasi selama 1 x 24 jam pada suhu ruang. Hasil positif apabila media menjadi keruh dan negatif apabila tidak ada perubahan pada media.

\section{Analisis Data}

Data dianalisis secara deskriptif. Uji kemampuan bakteri diazotrof dalam menghasilkan
IAA dengan metode Salkowski dan uji kemampuan bakteri diazotrof dalam menambat $\mathrm{N}_{2}$ menggunakan metode Kjeldahl disajikan dalam bentuk tabel. Penentuan identitas bakteri dilakukan dengan mengidentifikasi hasil pengamatan morfologi, fisiologi, dan biokimiawi berdasarkan Bergeys Manual of Determinative Bacteriology Second Edition.

\section{HASIL DAN PEMBAHASAN}

\section{Isolasi Bakteri Diazotrof}

Hasil pengukuran nilai $\mathrm{pH}$ tanah pada rizosfer tanaman bawang merah (Allium ascalonicum L) di kecamatan Larangan, Kabupaten Brebes pada 3 lokasi pengambilan sampel, berkisar antar 6-6,1(Tabel 1.). Menurut Firmansyah et al. (2015), tanah pertanian bawang merah di Brebes memiliki pH mulai dari asam sampai dengan alkalis (pH 5,6-8,5). Suhu tanah pada ketiga lokasi sampel $32,5-34,2^{\circ} \mathrm{C}$, dengan kelembaban tanah pada ketiga lokasi sampel dalam rentang 54\%-64\% (Tabel 1.). Jenis tanah lahan pertanian bawang merah Brebes merupakan tanah jenis Alluvial (Entilisol) dan berstekstur liat (Sumarni et al., 2012). Reaksi tanah $(\mathrm{pH})$, kelembaban, suhu, aerasi, drainase yang baik, kandungan bahan organik, serta kondisi perakaran tumbuhan menentukan sebaran bakteri penambat $\mathrm{N}_{2}$ (Agustian et al., 2012). Bakteri penambat nitrogen dapat tumbuh dalam rentang $\mathrm{pH}$ 4,5-8,5, dan kelembaban tanah antara 50\%-65\% (Holt et al., 1994). Menurut Simanungkalit et al. (2006), suhu tanah yang baik untuk pertumbuhan bakteri diazotrof dalam rentang $25-35^{\circ} \mathrm{C}$. Kondisi lingkungan tempat pengambilan sampel tanah cenderung baik untuk pertumbuhan bakteri diazotrof. 
BioEksakta: Jurnal Ilmiah Biologi Unsoed

Volume 2, Nomor 3 (2020): 463 - 477

Tabel 1. Hasil Pengukuran Suhu, pH dan Kelembaban Tanah Rizosfer Bawang Merah

\begin{tabular}{lccc}
\hline Lokasi & Suhu $\left({ }^{\circ} \mathrm{C}\right)$ & $\mathrm{pH}$ & Kelembaban(\%) \\
\hline Dukuhturi & 32,8 & 6,0 & 64 \\
Larangan & 32,5 & 6,0 & 63 \\
Karanggale & 34,2 & 6,1 & 54 \\
\hline
\end{tabular}

Isolasi bakteri diazotrof dilakukan dengan menumbuhkan sampel tanah rizosfer tanaman bawang merah (Allium ascalonicum L.) pada medium bebas nitrogen, yaitu YMA+congo red untuk menumbuhkan bakteri Rhizobium (Rao, 1994), medium Caceres untuk menumbuhkan bakteri Azospirillum (Caceres, 1982), dan medium Asbhy untuk menumbuhkan bakteri Azotobacter (Rao, 1994). Ketiga genera tersebut merupakan kelompok jenis bakteri diazotrof . Hasil isolasi dari ketiga lokasi sampling didapatkan sebanyak 28 isolat (Tabel 2.), yang diberi kode sesuai lokasi sampling dan media perumbuhan. Sebanyak 14 isolat yang diperoleh dari medium YMA diberi kode isolat LAR1, LAR2, LAR3, LAR4, LAR5, LAR6 LBR1, LBR2, LBR3, LBR4, LCR1, LCR2, LCR3, dan LCR4. Isolat yang tumbuh pada medium YMA+ congo red memiliki karakteristik warna koloni putih susu atau merah muda, tidak transparan, bentuk koloni sirkuler, konveks, semi translusen, koloni bakteri lembek atau berlendir pada agar diduga merupakan bakteri dari genus Rhizobium (Surtiningsih et al., 2009). Hasil isolasi dari medium Caceres didapatkan sebanyak 9 isolat dengan kode isolat LAA1, LAA2, LAA3, LAA4, LAA5, LBA1, LBA2, LBA3, dan LCA1. Isolat yang didapatkan pada medium Caceres dengan karakteristik koloni berwarna merah, berbentuk bulat, tepi halus, dan elevasi rata mencirikan spesies anggota genus Azospirillum (Caceres, 1982). Sebanyak 5 isolat didapatkan pada medium Asbhy dan kode isolat LAZ1, LAZ2, LAZ3, LBZ1, dan LCZ1. Isolat yang diperoleh pada medium Asbhy memiliki karakter koloni berwarna bening atau putih, dengan bentuk circular, irregular; elevasi convex, effuse; bentuk tepi undulate, crenate mencirikan spesies anggota genus Azotobcter (Yulitaasary et al., 2017) (Tabel 2.).

Tabel 2. Lokasi Sampel dan Bakteri Dizotrof Hasil Isolasi

\begin{tabular}{|c|c|c|c|}
\hline Lokasi Pengambilan Sampel & Medium & Kode Isolat & Genus \\
\hline \multirow[t]{6}{*}{ Dukuhturi } & & LAR1 & \\
\hline & & LAR2 & \\
\hline & & LAR3 & \\
\hline & & LAR4 & \\
\hline & & LAR5 & \\
\hline & & LAR6 & \\
\hline \multirow[t]{4}{*}{ Larangan } & Yoost Monitel Aror & LBR1 & Phizhium \\
\hline & Yeast Manitol Agar & LBR2 & Rhizobium \\
\hline & & LBR3 & \\
\hline & & LBR4 & \\
\hline \multirow[t]{4}{*}{ Karanggale } & & LCR1 & \\
\hline & & LCR2 & \\
\hline & & LCR3 & \\
\hline & & LCR4 & \\
\hline \multirow[t]{5}{*}{ Dukuhturi } & & LAA1 & \\
\hline & & LAA2 & \\
\hline & Caceres & LAA3 & Azospirillum \\
\hline & & LAA4 & \\
\hline & & LAA5 & \\
\hline
\end{tabular}




\begin{tabular}{lll} 
Larangan & LBA1 \\
& LBA2 & \\
& LBA3 & \\
Karanggale & LCA1 & \\
Dukuhturi & LAZ1 & Azotobacter \\
& & LAZ2 \\
Larangan & LAZ3 & \\
Karanggale & LBZ1 \\
\hline
\end{tabular}

Tabel 3. Kemampuan IAA Isolat Bakteri Diazotrof dalam Menghasilkan IAA

\begin{tabular}{lcc}
\hline No. & Kode Isolat & Konsentrasi IAA $(\mathrm{ppm})$ \\
\hline 1. & LCR3 & 3,22 \\
2. & LAR5 & 3,34 \\
3. & LBR1 & 3,21 \\
4. & LAZ2 & 3,05 \\
5. & LAZ3 & 3,05 \\
6. & LCA1 & 3,16 \\
7. & LAR3 & 3,51 \\
8. & LAA5 & 3,21 \\
9. & LAA4 & 3,35 \\
\hline
\end{tabular}

\section{Pengujian Kemampuan Bakteri Diazotrof dalam menghasilkan IAA}

Sebanyak 28 isolat bakteri diazotrof hasil isolasi diuji kemampuannya dalam menghasilkan IAA. Hasil pengukuran produksi IAA menunjukkan sebanyak 9 isolat mampu menghasilkan hormon IAA berkisar antara 3,05-3,51 ppm (Tabel 3.).

Hasil penelitian menunjukkan konsentrasi IAA tertinggi dihasilkan oleh isolat LAR3 sebesar 3,51 ppm. Isolat LAR3 dapat menghasilkan IAA dengan konsentrasi yang lebih tinggi dibandingkan dengan isolat bakteri diazotrof yang diisolasi dari rizosfer tanaman kelapa sawit yaitu 0,097 ppm (Walida et al., 2019). Isolat bakteri Rhizobium yang diisolasi dari tanah perkebunan karet, mampu menghasilkan IAA dengan konsentrasi sebesar 2,86 ppm, isolat Azospirillum sebesar 0,0429 ppm, dan isolat Azotobacter sebesar 0,0517 ppm (Widawati, 2015). Konsentrasi IAA yang dihasilkan oleh kesembilan isolat bakteri diazotrof dari rizosfer tanaman bawang merah lebih tinggi dibandingkan dengan yang dilaporkan oleh Widawati (2015).

\section{Kemampuan Bakteri Diazotrof dalam Menambat $\mathbf{N}_{2}$}

Pengukuran kemampuan fiksasi $\mathrm{N}_{2}$ isolat bakteri diazotrof didasarkan pada $\mathrm{N}$ - total menurut metode Kjeldahl. Dua isolat terbaik dari masingmasing anggota genus bakteri diazotrof dipilih untuk pengujian kemampuan penambatan $\mathrm{N}_{2}$. Menurut Wiyantoko et al. (2017), penentuan kemampuan penambatan $\mathrm{N}_{2}$ menggunakan metode Kjeldahl dihitung berdasarkan $\mathrm{N}$ total yang terdiri atas nitrat $\left(\mathrm{NO}^{3-}\right)$ amonium $\left(\mathrm{NH}^{4+}\right)$ dan $\mathrm{NH}_{3}$. Prinsip metode ini adalah sampel padat dihidrolisis dengan asam sulfat membentuk senyawa amonium sulfat. Senyawa nitrat dengan asam salisilat membentuk nitrosalisilat, kemudian akan direduksi dengan natrium tiosulfat dan akan terbentuk senyawa amonium. Produk hasil destruksi berupa senyawa amonium yang kemudian didestilasi dalam suasana alkali dan ditampung dengan asam borat. Hasil destilasi yang dihasilkan berwarna hijau dan selanjutnya hasil destilasi dititrasi sampai berubah warna merah muda. Banyaknya $\mathrm{N}$ yang diperoleh berdasarkan nilai titrasi dengan $\mathrm{HCl}$ sebagai titer.

Hasil pengukuran $\mathrm{N}$ total bakteri isolat diazotrof dari rizosfer tanah bawang merah (LAA4, LAA5, LAZ2, LAZ3, LAR3, LAR5) berkisar antar 3,50-88,55 ppm. Kemampuan penambatan $\mathrm{N}_{2}$ Rhizobium lebih tinggi daripada Azotobacter dan Azospirillum (Tabel 4.). Isolat LARH5 
BioEksakta: Jurnal Ilmiah Biologi Unsoed

Volume 2, Nomor 3 (2020): 463 - 477

menghasilkan nitrogen lebih tinggi dibandingkan dengan hasil penelitian Ummah et al. (2019) terhadap bakteri yang diisolasi dari tanah pertanian tanaman bawang merah yaitu sebesar 4,55 ppm dengan waktu inkubasi selama 2 hari. Menurut Raffi \& Charyulu (2012), berdasarkan hasil penelitiannya pada Azospirillum spp. yang diisolasi dari rizosfer dan non rizosfer tanah serealia, menghasilkan nitrogen dengan rentang 2,95 sampai 12,4 ppm dengan waktu inkubasi selama 45 hari.
Menurut Allito et al. (2020) isolat bakteri Rhizobium yang diisolasi dari tanaman legum mampu menambat $\mathrm{N}_{2}$ sebesar 85,5-87,5 ppm. Menurut penelitian yang dilakukan Ricard et al. (2018), isolat bakteri kelompok genus Azotobacter yang berasal dari rizosfer tanaman jagung mampu menambat $\mathrm{N}_{2}$ sebesar 3 ppm. Kemampuan keenam isolat dalam memfiksasi $\mathrm{N}_{2}$ lebih tinggi dari yang dilaporkan Raffi \& Charyulu (2012), Ricard et al. (2018); Allito et al. (2020).

Tabel 4. Kemampuan Bakteri Diazotrof dalam Menambat $\mathrm{N}_{2}$

\begin{tabular}{lcc}
\hline No. & Kode Isolat & Konsentrasi N total $(\mathrm{ppm})$ \\
\hline 1. & LAA4 & 3,50 \\
2. & LAA5 & 6,65 \\
3. & LAZ2 & 14,00 \\
4. & LAZ3 & 7,00 \\
5. & LAR3 & 87,15 \\
6. & LAR5 & 88,55 \\
\hline
\end{tabular}

Kelompok bakteri diazotrof mampu menstimulasi pertumbuhan tanaman karena bakteri yang dikonsorsiumkan mempunyai hubungan sinergis yang baik dalam penambatan $\mathrm{N}$ dan pelarutan $\mathrm{P}$, sehingga mampu meningkatkan ketersediaan hara atau memproduksi fitohormon pemacu tumbuh tanaman yang meningkatkan pertumbuhan serta produktivitas tanaman (Halmedan et al., 2017). Fiksasi nitrogen oleh bakteri yang mampu menambat $\mathrm{N}_{2}$, yaitu bakteri yang hidup bebas atau bersimbiosis pada tanaman legum. Fiksasi Nitrogen melibatkan ATP dan proses reduksi ekivalen yang berasal dari metabolisme primer. Semua reaksi yang terjadi dikatalisis oleh nitrogenase. Nitrogenase merupakan enzim kompleks yang terlibat dalam proses fiksasi nitrogen. Nitrogenase berperan dalam pengubahan bentuk nitrogen bebas di udara menjadi amonia $\left(\mathrm{NH}_{3}\right)$ (Susilowati \& Setyowati, 2016). Purwanto et al. (2017) menyebutkan bahwa inokulasi bakteri diazotrof pada tanaman padi dapat meningkatkan panjang akar total dan produksi biomassa. Bakteri diazotrof yang berasal dari rizosfer tanaman padi yang dilaporkan memiliki aktivitas nitrogenase dalam rentang 0,04-0,07 $\mu \mathrm{M}$.

\section{Identifikasi Bakteri Diazotrof}

Hasil pengamatan isolat bakteri diazotrof asal rizosfer tanah bawang merah (LAA4, LAA5,LCA1) yang ditumbuhkan pada medium Caceres yaitu sebagian besar koloni berwarna merah. Medium Caceres merupakan medium selektif bagi Azospirillum yang ditandai dengan koloni berwarna merah. Koloni bakteri yang tumbuh pada medium Caceres juga memiliki bentuk bulat (circuler) dan tidak teratur (irregular), elevasi rata (flat) dan timbul (raised), serta memiliki tepi (margin) entire (Tabel 5.). Koloni bakteri Azospirillum berbentuk bulat, tepi halus, dan memiliki elevasi rata (Caceres, 1982). Beberapa strain memiliki elevasi datar dan timbul (Pangestika et al., 2017).

Hasil pengamatan mikromorfologi berbentuk batang, sifat Gram negatif, motil dan nonmotil (Tabel 5.). Menurut Hot et al. (1994); Cowan et al. (1993), bakteri dari anggota genus Azospirillum sel berbentuk vibroid atau batang, sel bersifat Gram negatif. Spesies anggota Azospirillum memiliki flagella sehingga motil, namun dalam kondisi yang tidak memungkinkan dapat bersifat non motil. Oedjijono et al. (2014), 
juga menyebutkan bahwa Azospirillum merupakan bakteri yang hidup bebas di perakaran dan mampu memfiksasi nitrogen. Sel-selnya berbentuk batang dan vibroid, Gram negatif, motil, membentuk pelikel pada semisolid NfB.

Uji fisiologi yang dilakukan pada bakteri diazotrof yang diperoleh dari medium Caceres meliputi uji pengaruh suhu, uji pengaruh $\mathrm{pH}$, dan uji ketahanan terhadap salinitas. Hasil pengamatan pada pengaruh suhu terhadap pertumbuhan bakteri menunjukkan bahwa bakteri mampu tumbuh pada suhu ruang dan $37^{\circ} \mathrm{C}$, sedangkan pada suhu $50^{\circ} \mathrm{C}$ tidak mampu tumbuh. Ketiga isolat tersebut hanya mampu tumbuh pada $\mathrm{pH} 4$ dan 7. Pengujian perlakuan pada medium yang diberi salinitas berbeda, menunjukkan bahwa semua isoat bakteri mampu tumbuh pada konsentrasi $\mathrm{NaCl} 3 \%$, namun isolat LAA4 dan LAA5 mampu tumbuh pada medium dengan konsentrasi $\mathrm{NaCl}$ 5\%(Tabel 5.). Menurut Rasool et al. (2015), Azospirillum memiliki pertumbuhan optimum pada suhu $30^{\circ} \mathrm{C}$ dengan kisaran pH 6-7. Santoso et al. (2019), menyebutkan bahwa suhu pertumbuhan Azospirillum yaitu $27-29^{\circ} \mathrm{C}$, dengan $\mathrm{pH}$ 6,9-7, dan konsentrasi $\mathrm{NaCl}$ sebesar $3 \%$.

Pengujian biokimia terhadap isolat yang didapatkan dari medium Caceres meliputi uji oksidase, uji katalase, uji produksi asam dari karbohidrat, uji oksidatif-fermentatif. Hasil pengamatan menunjukkan ketiga isolat positif oksidase. Isolat LAA4 dan LCA1 bersifat fermentatif, dan hanya isolat LAA5 yang bersifat oksidatif-fermentatif. Ketiga isolat mampu mengubah asam pada medium yang mengandung glukosa. Isolat LAA4 dan LCA1 mampu menghasilkan asam pada medium yang mengandung sukrosa, dan hanya isolat LAA4 yang mampu menghasilkan asam dari medium dengan penambahan laktosa. Pengamatan uji katalase menunjukkan ketiga isolat negatif untuk uji katalase (Tabel 5.). Kelompok bakteri Azospiriillum memiliki kemampuan menghasilkan enzim katalase ditandai dengan positif pada uji katalase, namun beberapa isolat negatif pada uji katalase, sedangkan beberapa isolat mampu menghasilkan enzim oksidase dan beberapa negatif pada saat uji oksidase (Pangestika, et al., 2017. Menurut Hot et al. (1994) Azospirillum mampu mengubah asam pada medium yang mengandung maltosa, laktosa, D-mannosa, Sitrat, laktat, D-sorbitol, D-ribose.

Berdasarkan pengamatan uji gula sebagai sumber karbon satu-satunya menunjukkan ketiga isolat (LAA4, LAA5, dan LCA1) mampu tumbuh pada medium yang mengandung glukosa sebagai sumber karbon. Isolat LAA4 dan LCA1 mampu tumbuh pada medium basal dengan sumber karbon sukrosa dan maltosa. Isolat LAA5 dan LCA1 dapat tumbuh pada medium basal dengan sumber karbon dari laktosa (Tabel 5.). Azospirillum agricola sp. nov. dapat menggunakan sumber karbon yang berasal dari gula seperti arabinosa, fruktosa, galaktosa, asam piruvat, asam suksinat, asam asetat, asam sitrat, dan glukosa 6-fosfat (Lin et al., 2016). Beberapa isolat mampu menggunakan glukosa, laktosa, dan sukrosa sebagai sumber karbon, sebagian ada yang hanya dapat menggunakan glukosa sebagai sumber karbon. Menurut Trivendi et. al. (2010), penggunaan jenis gula sebagai sumber karbon dipengaruhi oleh aktivitas enzimatis di dalam sel. Mikroorganisme tidak semua dapat menggunakan semua jenis gula sebagai sumber karbon, karena keterbatasan aktivitas enzim. Keterbatasan dalam menggunakan jenis gula tertentu sebagai sumber karbon dapat digunakan sebagai kunci melakukan identifikasi terhadap jenis tertentu

Hasil pengamatan bakteri diazotrof asal rizosfer tanah pertanian bawang merah (LAZ2 dan LAZ3) asal rizosfer tanah pertanian bawang merah yang didapatkan dari medium Asbhy menunjukkan koloni berwarna putih bening. Koloni bakteri Azotobacter sebagian koloni berwarna bening, 
berbentuk bulat (circuler), memiliki elevasi convex dan datar (flat), tepi (margin) rata (entire) dan berukuran kecil serta punctiform. Kelompok bakteri Azotobacter memiliki koloni yang berwarna putih atau bening saat ditumbuhkan di media Asbhy (Islam et al., 2019). Hal yang sama dijelaskan bahwa koloni Azotobacter dapat berwarna putih, bening, keruh, dan coklat (Wedastri, et al. 2002). Menurut hasil penelitian Santoso et al. (2019), menunjukkan karakter morfologis koloni Azotobacter berbentuk bulat, tepian tidak rata, elevasi konveks.

Hasil pengamatan morfologi sel memiliki bentuk bulat (coccus) dan Gram negatif, dan bersifat motil (Tabel 5.). Menurut Holt et al. (1994) dan Cowan et al. (1993), anggota genus Azotobacter memiliki sel berbentuk ovoid, batang maupun kokus, bakteri bersifat Gram negatif. Kelompok bakteri Azotobacter bersifat motil karena memiliki flagella, namun pada beberapa jenis lain tidak memiliki flagella sehingga nonmotil. Hal yang sama juga dilaporkan oleh Rahmi (2014), Azotobacter merupakan bakteri yang bersifat motil yang bergerak menggunakan flagel, dengan kecepatan pergerakan yang berbeda-beda.

Hasil pengamatan pada uji fisiologi pada bakteri diazotrof yang diperoleh dari medium Asbhy (LAZ2 dan LAZ3). Kedua isolat bakteri dapat tumbuh pada suhu ruang dan suhu $37^{\circ} \mathrm{C}$, positif pada $\mathrm{pH}$ medium 4 dan 7 , dan mampu tumbuh pada medium dengan konsentrasi $\mathrm{NaCl} 3 \%$ (Tabel 5.). Hal ini sesuai dengan pernyataan Packialakshmi \& Aliya (2014), bakteri genus Azotobacter mampu tumbuh pada suhu $28^{\circ} \mathrm{C}$ dan $30^{\circ} \mathrm{C}$, dan dapat tumbuh dengan baik pada $\mathrm{pH} 7,5$ dan 7,45. Menurut penelitian yang dilakukan Agustian et al. (2012), genus Azotobacter tumbuh optimum pada $\mathrm{pH} 7$, namun pada $\mathrm{pH} 4$ masih dapat tumbuh. Kelompok anggota Azotobacter mampu tumbuh pada NaCL 3\%, sehingga bakteri ini mampu hidup dikondisi salin. Holt et al. (1994) dalam Bergey's Manual of Determinative Bacteriology menyebutkan bahwa, anggota Azotobacter dapat tumbuh pada rentang $\mathrm{pH} 4,8-8,5$, dan memiliki $\mathrm{pH}$ optimum untuk fiksasi nitrogen antara 7,0-7,5.

Hasil pengamatan biokimia pada isolat yang didapat dari medium Asbhy, Kedua positif pada uji katalase, isolat mampu memproduksi asam dari sumber glukosa, dan bersifat fermentatif. Uji nutrisional yang dilakukan menunjukkan bakteri mampu menggunakan glukosa sebagai sumber karbon satu-satunya (Tabel 5.). Menurut Agisti et al. (2014), karakter kunci dari genus Azotobacter adalah sel berbentuk cocoid, oksidase negatif, katalase positif dan membentuk kista yang merupakan mekanisme melindungi dari keadaan lingkungan yang ekstrim. Holt et al. (1994) dalam Bergey's Manual of Determinative Bacteriology menyebutkan, Azotobacter mampu menggunakan glukosa sebagai sumber karbon satu-satunya, serta mampu memfermentasikan glukosa, sukrosa dan latosa.

Hasil pengamatan morfologi isolat bakteri diazotrof asal rizosfer tanah pertanian Bawang merah di Brebes (LAR3, LAR5, LBR1, dan LCR3) yang diperoleh dari medium YMA + congo red menunjukkan isolat bakteri memiliki koloni berwarna merah muda dan putih, memiliki bentuk Circuler dan irregular, berbentuk kecil dan ada yang besar, elevasi raised, convex, flat dan umbonate, serta memiliki tepi entire dan raised (Tabel 5.). Menurut Sari et al. (2018), isolat Rhizobium yang ditumbuhkan di medium YMA+ congo red memiliki warna pink, atau putih karena bakteri Rhizobium tidak dapat menyerap warna merah. Surtiningsih et al. (2009), menjelaskan karakteristik bakteri Rhizobium secara makroskopis adalah warna koloni putih susu, tidak transparan, bentuk koloni sirkuler, konveks, semitranslusen, diameter 2 - $4 \mathrm{~mm}$ dalam waktu 
3 - 5 hari pada agar YMA+congo red. Hal ini sesuai dengan penjelasan Holt et al. (1994) dalam Bergey's Manual of Determinative Bacteriology, kelompok Rhizobium koloni berbentuk circular, convex, putih, semi translucent atau opaque, raised.

Hasil pengamatan mikromorfologi bakteri diazotrof yang didapat pada medium YMA+congo red bersifat Gram negatif, berbentuk batang, dan motil (Tabel 5.). Karakter mikroskopis sel bakteri Rhizobium berbentuk batang, aerobik, Gram negatif dengan ukuran $0,5-0,9 \times 1,2-3 \mu \mathrm{m}$, bersifat motil pada media cair, umumnya memiliki satu flagella polar atau subpolar (Surtiningsih et al., 2009). Menurut Holt et al. (1994) dalam Bergey's Manual of Determinative Bacteriology, aggota genus Rhizobium berbentuk batang, motil dengan flagella. Menurut Dutta \& Podile (2010), sifat motil penting bagi bakteri PGPR dikarenakan motilitas bakteri berperan dalam kolonisasi akar.

Hasil pengamatan uji fisiologi pada isolat bateri yang diperoleh dari medium YMA+congo red dapat tumbuh suhu ruang dan $37^{\circ} \mathrm{C}$, medium dengan $\mathrm{pH} 4$ dna 7, dan mampu tumbuh pada medium dengan $\mathrm{NaCl} 3 \%$ dan 5\% (Tabel 5.). Menurut Holt et al. (1994), Kelompok bakteri Rhizobium memiliki suhu optimum dalam rentang $4^{\circ} \mathrm{C}-40^{\circ} \mathrm{C}$, namun optimum pada kisaran $30^{\circ} \mathrm{C}$. Genus Rhizobium mampu tumbuh pada rentang $\mathrm{pH}$ 4-10. Hal ini sesuai dengan pernyataan Nasikah (2007), bahwa suhu optimal untuk Rhizobium berkisar $18^{\circ} \mathrm{C}-26^{\circ} \mathrm{C}$, minimal $3{ }^{\circ} \mathrm{C}$ dan maksimal $45^{\circ} \mathrm{C}$. Sedangkan kisaran $\mathrm{pH}$ optimal untuk Rhizobium adalah sedikit di bawah netral hingga agak alkali, kendati demikian pada pH 5,0 beberapa strain Rhizobium masih dapat bertahan hidup.

Hasil pengamatan uji biokimia pada isolat yang didapat di medium YMA+congo red menunjukkan positif pada katalase, keempat isolat mampu memproduksi asam dari sumber karbon glukosa. Isolat bakteri diazotrof LAR3, LAR5, LCR3 mampu mereduksi asam dari sumber gula jenis sukrosa. LAR3 dan LAR5 mampu memproduksi asam dari laktosa. Hasil uji fermentatif dan oksidatif, menunjukkan isolat LAR5, LBR1, dan LCR3 bersifat oksidatiffermentatif. Isolat LAR3 bersifat fermentatif. Pengamatan uji oksidase menunjukkan keempat isolat negatif (Tabel 5.). Enzim katalase berfungsi untuk menguraikan hidrogen peroksida yang bersifat racun bagi sel dan menghasilkan gas oksigen dana air sesuai reaksi (Pelczar \& Chan 2008).

Hasil uji nutrisional yg diamati yaitu uji karbohidrat sebagai sumber satu-satunya karbon. Isolat bakteri diazotrof LAR3 dan LCR3 mampu menjadikan glukosa, laktosa, sukrosa, dan maltosa sebagai sumber karbon satu-satunya. Isolat bakteri diazotrof LBR1 mampu menjadikan laktosa, sukrosa, dan maltosa sebagai sumber karbon satusatunya, LAR3 hanya mampu menjadikan glukosa sebagai sumber karbon satu-satunya. (Tabel 5.). Menurut de Lajudie et al. (1994) dalam Bergey's Manual of Determinative Bacteriology , Rhizobium menggunakan glukosa, laktosa, sukrosa, maltosa, malonat, argunin, glukonat sebagai sumber karbon. Sari \& Retno (2015), menjelaskan Rhizobium bersifat kemoorganotropik, yaitu dapat menggunakan berbagai karbohidrat dan garam-garam asam organik sebagai sumber karbonnya.

Berdasarkan hasil pengamatan terhadap karakter morfologi, fisiologi, biokimia, dan nutrisional serta mengacu kepada Bergey's Manual of Determinative Bacteriology bahwa isolat LAA4, LA5, LCA1 termasuk spesies anggota genus Azospirillum, kemudian isolat LAZ2 dan LAZ3 termasuk spesies anggota genus Azotobacter, dan isolat LAR3, LAR5, LBR1, LCR3 merupakan spesies anggota genus Rhizobium. 

Tabel 5. Hasil Karakterisasi Isolat Bakteri Diazotrof

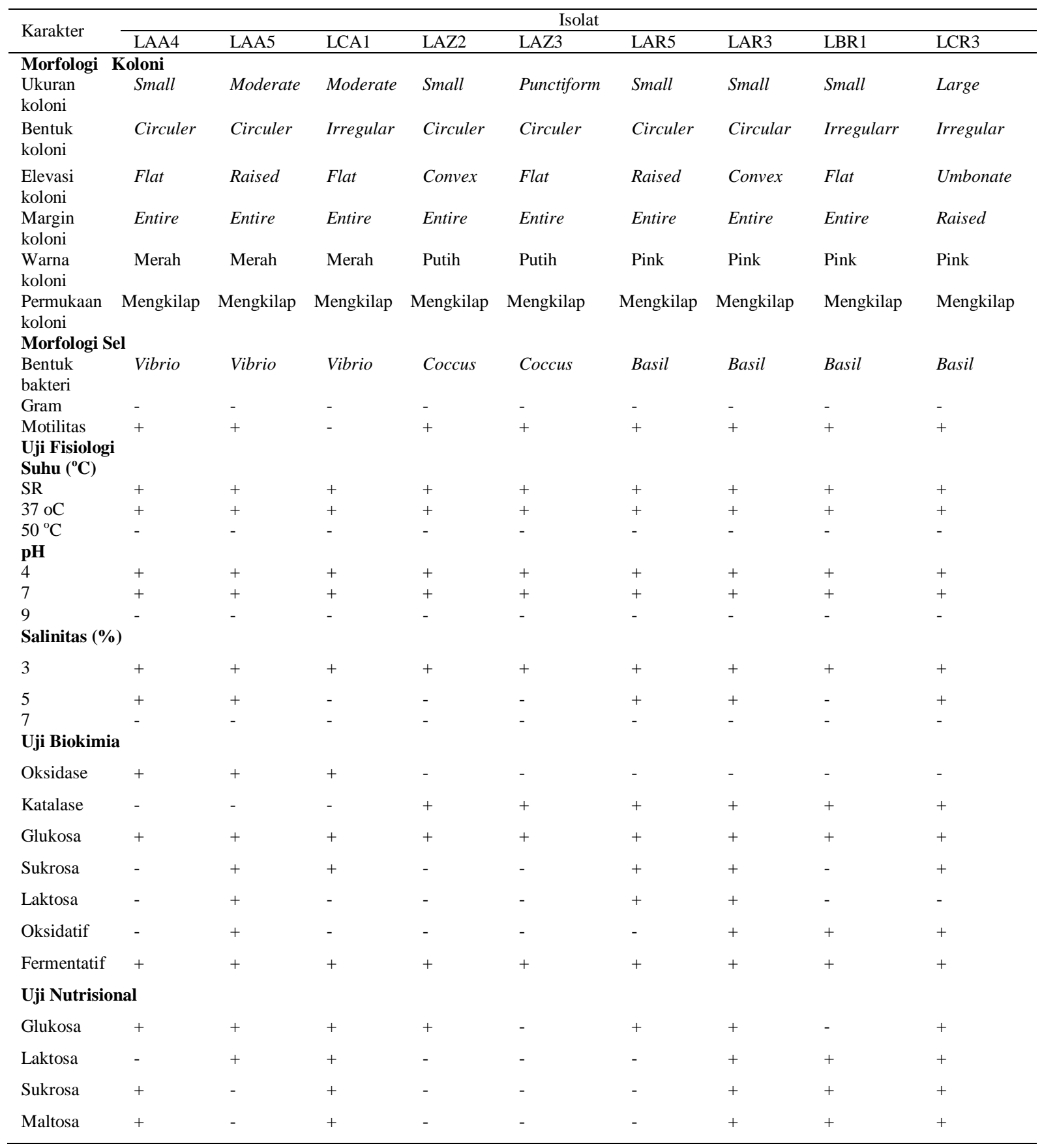

\section{SIMPULAN}

Berdasarkan hasil dan pembahasan di atas, dapat disimpulkan bahwa sebanyak 28 isolat bakteri diazotrof dari rizosfer bawang merah (Allium ascalonicum L.) Brebes, Jawa Tengah berhasil diisolasi. Sembilan dari 28 isolat bakteri diazotrof (LAA4, LAA5, LCA1, LAR3,LAR5,LBR1,LCR3, LAZ2, dan LAZ3) mampu menghasilkan hormon IAA berkisar antara
3,05-3,51 ppm, dengan isolat LAR3 sebagai penghasil IAA tertinggi. Sebanyak enam isolat bakteri diazotrof penghasil IAA terbaik (LAA4,LAA5,LAR3,LAR5, LAZ2, dan LAZ3) mampu menambat nitrogen berkisar antara 3,5088,55 ppm, dengan isolat LAR5 sebagai penghasil nitrogen tertinggi. Isolat bakteri diazotrof LAA4, LAA5, dan LCA1 diidentifikasi sebagai spesies anggota genus Azospirillum, isolat bakteri 
diazotrof LAZ2 dan LAZ3 merupakan spesies anggota genus Azotobacter, isolat bakteri diazotrof LAR3, LAR5, LBR1, dan LCR3 merupakan spesies anggota genus Rhizobium.

\section{DAFTAR PUSTAKA}

Adiguzel, A., Bektas, K. I., Sahin, F. \& B. Özlem., 2011. Molecular Diversity Of Thermophilic Bacteria Isolatd Adiguzel From Pasinler Hot Spring (Erzurum, Turkey). Turkish Journal of Biology, 35 (3) : 267-274.

Agisti, A., Nur, H. A., \& Tutik, N. Hidayati, 2014. Isolasi dan Dentifiasi Bakteri Penambat Nitrogen Non Simbiotik pada Lahan Restorasi dengan Metode Legume Cover Crop (LCC) di Daerah Pasirian Lumajang Jawa Timur. Jurnal Sains Dan Seni Pomits, $3(2): 36-39$.

Agustian, R. Syafei, \& L. Maria., 2012. Keragaman Bakteri Penambat N Pada Rhizosfir Titonia (Tithonia diversifolia) Yang Tumbuh Pada Tanah Masam Ultisol. Jurnal Solum, 9 (2) : 98-105.

Allito, Bunkura B., Nana Ensuwi-Mensah, \& Vimcent L., 2020. Legume-Rhizobium Strain Specifity Enchanes Nutrition and Nitrogen Fixation in Faba Bean (Vica faba L.). Journal Agronomy, 10 (82) : 1-21.

APPI., 2015. Kebutuhan pupuk urea 2006-2015. http://www.appi.or.id/ images/ statistic/ KEBUTUHAN_PUPUK_UREA_2006__2015.xls. Diunduh tanggal 15 Mei 2019.Atlas, R., Brown, A., Dobra, K. \& Miller, L., 1984 Experimental Microbiology. New York: Macmillan Publishing Company.

Bergey, D. H., \& Boone, D., 2009. Bergey's Manual of Determinative Bacteriology. $2^{\text {nd }}$ Edition. New York: Sringer SciencesBusiness Media.

Brown, A. E., 2007. Microbiological Applications. New York : Higher Education.

Cowan, ST, Steel, KJ, Barrow, GI, \& Feltham, RKA.,1993. Cowan and Steel's Manual for The Identification of Medical Bacteria. 3rd Edition. Australia: Cambridge University Press.

Danapriatna, N., 2010. Biokimia Penambatan Nitrogen oleh Bakteri Non Simbiotik. Jurnal Agribisnis \& Pengembangan Wilayah, 1 (2): $1-10$.

de Lajudie, P., A. Willems, B. Pot, D. Dewettinck, G. Maestrojuan, M.Neyra, M.D. Collins, B.
Dreyfus, K. Kersters and M. Gillis., 1994. Polyphasic taxonomy of rhizobia: emendation of the genus Sinorhizobium and description of Sinorhizobium meliloti comb. nov.,Sinorhizobium saheli sp. nov., and Sinorhizobium teranga sp. nov. International Jurnal. Systematic Bacterioly, $44: 733$.

Firmansyah, I., Liferdi, Khaririyatun, N., \& Yufdy, MP., 2015. Pertumbuhan dan Hasil Bawang Merah dengan Aplikasi Pupuk Organik dan Pupuk Hayati pada Tanah Alluvial (The Growth and Yield of Shallots with Organic Fertilizers and Biofertilizers Application in Alluvial Soil). Jurnal Hortikultura, 25 (2): 133-144.

Halmedan, J., Yogi S., Sudiarso., 2017. Respon Tanaman Jagung Manis (Zea mays saccharata) Terhadap Aplikasi Plant Growth Promoting Rhizobacteria (PGPR) Dan Pupuk Kandang Ayam. Jurnal Produksi Tanaman, 5(12).

Hindersah, R. \& Simarmata T., 2004. Kontribusi rizobakteri Azotobacter Dalam Meningkatkan Kesehatan Tanah Melalui Fiksasi $\mathrm{N}_{2}$ Dan Produksi Fitohormon Di Rizosfer. Jurnal Nature Indo, 6 : 127-133

Holt, J.G., Krieg, N.R., Sneath, P.H.A., Staley, J.T., \& William, S.T., 1994. Bergey's Manual of Determinative Bacteriology. $2^{\text {nd }}$ Edition. New York: Lippicolt William and Wilkins.

Islam, H., Nelvia, N., \& Zul, D., 2019. Isolasi Dan Uji Potensi Bakteri Diazotrof Non Simbiotik Asal Tanah Kebun Kelapa Sawit Dengan Aplikasi Tandan Kosong Dan Limbah Cair Pabrik Kelapa Sawit. Jurnal Agroteknologi, 9(2) : 35-40.

Lay, B. W., 1994. Analisis Mikroba di Laboratorium. Jakarta: PT Raja Grafindo Persada.

Nasikah., 2007. Pengaruh Inokulasi Rhizobium Dan Waktu Pemberian Pupuk N (Urea) Terhadap Pertumbuhan Dan Hasil Kedelai Di Lahan Sawah Setelah Kedelai (Glycine max L. Merri). Skripsi. Malang: Fakultas Sains dan Teknologi. Universitas Islam Negeri Malang, Malang.

Oedjijono, E. S., Soetarto, S., \& Moeljopawiro, S., 2014. Promising plant growth promoting rhizobacteria of Azospirillum spp. isolatd from iron sand soils, Purworejo coast, central Java, Indonesia. Advances in Applied. Science Research., 5 : 302-308.

Packialakshmi, N. \& Aliya, R. T., 2014. Comparative Study of Vermicast and 
Charcoal Used as a Carrier Inoculums to the Biofertilizer Preparation. BMR journals, 1 (1) : 1-6.

Pangestika, R., Oedjijono, Lestanto, U. W., 2017. Populasi Azospirillum spp. Pada Rhizosfer Ilalang (Imperata cylindrica (L.) Beauv.) yang Tumbuh Di Lingkungan Berbeda. Journals Science Pharmacy, 3 (2) : 21-28.

Panjaitan, A., Anas, I., Widyastuti, R., \& Widayati, W. E., 2015. Kemampuan Bakteri Diazotrof Endofit Untuk Meningkatkan Pertumbuhan Vegetatif Bibit Kelapa Sawit (Elaeis guineensis jacq). Jurnal Ilmu Tanah dan Lingkungan, 17(1) : 1-7.

Purwanto, Yuyun, Y., Sumadi \& Tualar, S., 2017. Nitrogenase Activity and IAA Production of Indigenous Diazotroph and Its Effect on Rice Seedling Growth. AGRIVITA Journal of Agricultural Science, 39(1) : 31-37

Raffi, MMD., Charyulu, PBBN., 2012. Nitrogen Fixation by the Native Azotospirillum spp. Isolat from Rhizosphere and NonRhizosphere of Foxtail Millet. Asian Journal Biological and Life Science, 1 (3) : 213-218.

Rahmi., 2014. Kajian Efektifitas Mikroba Azotobacter sp. Sebagai Pemacu Pertumbuhan Tanaman Kakao (Theobroma cacao L.). Jurnal Galung Tropika, 3 (2) : 44-53.

Ramadhaniah, F. A., 2013. Keragaman Bakteri Endofit pada Kultivar Nanas (Ananas comosus (L.) Merr) Leor dan Duri di Kabupaten Subang. Skripsi. Bandung : Universitas Pendidikan Indonesia.

Rasool, L., A. asghari, A. Jamil and S.U. Rehman., 2015. Identification of Azospirillum Spesies from Wheat Rhizosphere. The Journal of Animal \& Plant Sciences, 25(4) : 1081-1086.

Reetha, S., Bhuvaneswari, G., Thamizhiniyan, P. \& Mycin, T. R., 2014. Isolation of indole acetic acid (IAA) producing rhizobacteria of Pseudomonas fluorescens and Bacillus subtilis and enhance growth of onion (Allium cepa L.). International Journal of Current Microbiology and Applied Science, 3(2) : 568-574.

Ricard, Patrick O., Abimbola O. A., Adenlyl A. O., 2018. Screening of bacteria isolatd from the rhizosfer of maize plant (Zea mays L.) form ammonia production and nitrogen fixation. African Journal of Microbiology Research,12 (34) :. 829-834.
Santoso, K., Rahmawati, Rafdinal., 2019. Eksplorasi Bakteri Penambat Nitrogen dari Tanah Hutan Mangrove Sungai Peniti, Kabupaten Mempawah. Jurnal Protobiont, 8 (1) : 52-58.

Saragih, D., Herawati H., \& Niar Nurmauli., 2013. Pengaruh Dosis Dan Waktu Aplikasi Pupuk Urea Dalam Meningkatkan Pertumbuhan Dan Hasil Jagung (Zea Mays, L.) Pioneer 27. Jurnal Agrotek Tropika, 1 (1): 50-54.

Sari, E., Anggi, Nico F., Zulvia, Intan S., \& Eman S., 2018. Isolasi Dan Karakterisasi Rhizobium Dari Glycine max L. Dan Mimosa pudica Linn. Jurnal Penelitian Biologi, 3 (2) : 55-62.

Sari, Ramdana, \& Retno P., 2015. Rhizobium: Pemanfaatannya Sebagai Bakteri Penambat Nitrogen. Info Teknis Ebotani, 12 (1) : 5164.

Simanungkalit, R., D., M., Rasti S., Ratin Dewi H., \& Edi H., 2006. Bakteri Penambat Nitrogen., Dalam buku Pupuk Organik dan Pupuk Hayati. Balai Litbang Sumberdaya Lahan Pertanian. Badan Litbang Pertanian.

Surtiningsih, T., Farida, \& T. Nurhariyati., 2009. Biofertilisasi Bakteri Rhizobium pada Tanaman Kedelai (Glycine $\max (\mathrm{L})$ Merr.). Berk. Penel. Hayati, 15 : 31-35.

Susilowati, Dwi N., \& Setyowati, M., 2016, Analisis Aktivitas Nitrogenase Dan Gen nifh Isolat Bakteri Rhizosfer Tanaman Padi dari Lahan Sawah Pesisir Jawa Barat. Journal of Biology, 9 (2) : 126-137.

Tilak K.V.B.R., K.K. Pal, R. Dey., 2010. Microbes for sustainable agriculture, I.K. New Delhi, India: International Publishing House Pvt. Ltd.

Trivendi, P.C., Pandey, S., \& Bhadauri., 2010. Text Book of Microbiology. Jaipur India : Aavishkar Publisher Distributors.

Ummah, R., Mahanani, T. S., Pramita, Y., 2019. Potensi Isolat Bakteri Endofit Akar Tanaman Bawang Merah (Allium ascalonicum) sebagai Penambat Nitrogen. Jurnal LenteraBio, 8 (2) : 143-149.

Walida, H., Fitra, S. H., Miranda, H., Febri, F. Y., 2019. Isolasi Dan Identifikasi Bakteri Penghasil Iaa Dan Pelarut Fosfat Dari Rhizosfer Tanaman Kelapa Sawit. Jurnal Biologi Lingkungan, Industri, dan Kesehatan, 6 (2) : 1-7.

Wedastri, S. 2002., Isolasi dan Seleksi Azotobacter spp. Penghasil Faktor Tumbuh dan 
Penambat Nitrogen dari Tanah Masam. J. Ilmu Tanah dan lingkungan, 3 : 45-51

Widiawati, S., 2015. Isolasi dan Aktivitas Plant Growth Promoting Rhizobacteria dari Tanah Perkebunan Karet, Lampung. Jurnal Berita Biologi, 14 (1) : 77-88.

Wiyantoko, B., P. Kurniawati, T. E., Purbaningtyas., 2017. Pengujian Nitrogen Total, Kandungan Air Dan Cemaran Logam Timbal Pada Pupuk Anorganik Nitrogen Phospor Kalium (NPK) Padat . Jurnal Sains dan Teknologi, 6 (1) : 51-60.

Yulitaasary, A. T., Asyiah, I. N., \& Iqbal, M., 2017. Isolasi Dan Identifikasi Azotobacter Dari Rhizosfer Tanaman Kopi (Coffea Canephora) Yang Terserang Nematoda Parasit Pratylenchus Coffeae. Saintifika, 19(2) : 13-23 